\title{
WATER AS THE ULTIMATE SINK: LINKING FRESH AND SALTWATER HISTORY
}

\author{
SIMONE M. MÜLLER AND DAVID STRADLING \\ Rachel Carson Center for Environment and Society \\ Ludwig Maximilian University
}

\section{Abstract}

This article draws marine and freshwater historiographies together through the narration of the anti-water-dumping movement of the late 1960s and early 1970s. Our research concerns the disposal of substances-pollution-into bodies of water and the growing public concern about the ecological and human consequences of those substances. One of us comes to the study of water from the perspective of river history, the other from that of ocean history. We follow scientific and policy debates, as well as public outrage over dredge spoil disposal in the Great Lakes and the disposal of chemical weapons, sewage and industrial waste in the Atlantic Ocean, linking both examples to the history of open-water dumping generally. Two fundamental qualities of water on earth-its tendency toward liquidity and opacity-are essential to the stories we tell. For the actors in our stories, these two qualities helped define water and influenced how they interacted with the ecosystems for which they expressed concern. We conclude, then, that these are stories that should be told together, that the presence of salt in one story matters much less than the presence of water in both. Our goal here is to explain why water historiography has been bifurcated and to make a plea for its unification.

Keywords: water pollution, marine histories, freshwater histories, environmental historiography

We humans have used nearby waters as sinks for all manner of waste for centuries. Water's qualities — especially its tendencies toward fluidity and opacity-enhanced its attraction as a waste disposal site. Increasingly over the twentieth century, humans discharged sewage and chemicals, disposed of dredge spoil and toxic waste, and drowned garbage and debris from municipal, industrial and agricultural sources in rivers, lakes, bays and even the open ocean. Neither the dilution nor the hiding of waste in water could prevent the development of problems for human health and natural environments. By the 1960s, water pollution, formerly largely a local or regional problem, had become a serious global concern. Untreated sewage and under-regulated industrial effluent were the major culprits, but citizens and politicians also expressed growing concern about all types of materials intentionally 
dumped in open waters. As communities learned more about the human and ecological effects of water pollution, the sight of open-water dumping became ever more troubling-irrespective of whether the sink was fresh or saltwater. For instance, in 1962, Anthony V. Collino, of Gibraltar, Michigan, complained about dredge spoil disposal he had witnessed while out on Lake Erie. 'The oil and scum rises to the top and floats around', he reported. 'All the filth that does not reach the lake by the natural current is taken out there by the dredge boat.' According to Collino, the dumping of spoil in open water threatened beaches, fishing and waterfowl habitat. ${ }^{1}$ Similarly, the New York Times warned in 1970, 'if the nation continued to use the seas as a dump ... the world's oceans [would] become as dead as Lake Erie'. ${ }^{2}$

This article draws marine and freshwater historiographies together through the narration of the anti-water dumping movement of the late 1960s and early 1970s. Our research concerns the disposal of substances-pollution—into bodies of water and the growing public concern about the ecological and human consequences of those substances. One of us comes to the study of water from the perspective of river history, the other from that of ocean history. We follow scientific and policy debates, as well as public outrage over dredge spoil disposal in the Great Lakes and the disposal of chemical weapons, sewage and industrial waste in the Atlantic Ocean, linking both examples to the history of open-water dumping generally. Two fundamental qualities of water on earth-its tendency toward liquidity and opacity-are essential to the stories we tell. For the actors in our stories, these two qualities helped define water and influenced how they interacted with the ecosystems for which they expressed concern. We conclude, then, that these are stories that should be told together, that the presence of salt in one story matters much less than the presence of water in both. Our goal here is to explain why water historiography has been bifurcated and to make a plea for its unification.

\section{Tübingen's puzzle}

The topic for this article came to us at a conference entitled 'Aquatic Histories in Transnational and Global Perspectives', held at Tübingen University, Germany, in the autumn of 2016. Ostensibly organised to bring together Russian/Soviet historians with those who study the West, the conference's mixing of water historians more emphatically resulted in exposing the gulf between those studying oceans and those studying fresh water. Historians working on these bodies of water asked very different questions and referenced completely separate historiographies depending

1 US Department of Health, Education, and Welfare, Transcript of Conference in the Matter of Pollution of the Navigable Waters of the Detroit River and Lake Erie and their Tributaries within the State of Michigan, vol. 2 (28 March 1962), 567-8.

2 'To Save the Seas', New York Times, 13 October 1970. 
on whether or not the water they studied contained salt. This distinction strikes us as problematic on its face and worthy of explication and repair. The need for a unified historiography of water is all the more apparent when one considers the relationships our actors had with and their understandings of water. Given new trends in environmental humanities toward material and planetary perspectives, we believe the time is right for the confluence of fresh and saltwater historiography.

'Water as the ultimate sink' introduces the respective historiographies of fresh and saltwater histories before considering how the material qualities of water-especially opacity, fluidity and to a certain degree tracklessness - can help us construct material and environmental histories that simultaneously span bodies of fresh and saltwater. In our focus on materiality, we followed the human perspective on water's characteristics — actual as well as imagined_-in two stories of aqueous disposal that posit the acts as water pollution. Moreover, in leaving our respective subfields of ocean and freshwater history and comparing and contrasting our individual stories, we learn that the understanding of bodies of water as hiding places have invited similar dumping practices, that people's concern about water's fluidity triggered environmental activism as well as political action, and that water's mobility called for transnational solutions. Irrespective of the level of salinity in the water, actors in our stories interacted very similarly with their respective body of water. Ultimately, this article asks, what might the broader field of environmental history gain by bringing fresh and saltwater histories together?

\section{Water's histories}

As the historian of fisheries Poul Holm has noted, river and ocean histories have participated in 'divergent scholarly communities'. ${ }^{3}$ As those who have studied salmon know, to follow anadromous fish out of rivers and into the ocean is to wade into an entirely different historiographical world. ${ }^{4}$ The separation can be partly explained by the physical differences in the bodies of water themselvesoceans present unique problems of scale, for example, given their vastness and depth. In addition, humans have thought about these two kinds of environments in very different ways. In particular, knowledge about fresh and salt waters has evolved differently_within distinct fields (limnology and oceanography) and at different rates. Historians have not only followed these two different scientific

\footnotetext{
3 Poul Holm made this comment while attending the 'Sea Flows: Mobility, Boundaries, and Scale in Marine Environmental History' panel at the 2017 American Society for Environmental History Conference in Chicago. Altogether this panel, including the presenters Mary Mendoza, Miles Alexander Powell, Jay Taylor and Lissa Wadewitz, influenced our thinking on both marine history and water history more generally.

4 See, for example, Arthur F. McEvoy, The Fisherman's Problem: Ecology and Law in the California Fisheries, 1850-1980 (New York: Cambridge University Press, 1986), doi.org/10.1017/CBO9780511583681; and Joseph E. Taylor, Making Salmon: An Environmental History of the Northwest Fisheries Crisis (Seattle, WA: University of Washington Press, 1999).
} 
trajectories in their work, but they have also relied on very different scientific source materials. Indeed, fresh and saltwater historians have very different bodies of sources available for their use, with freshwater scholars blessed with a much broader range of materials, while the ocean remains 'difficult to know' even in this day and age of science and technology. ${ }^{5}$ And, while bodies of both fresh and salt water have gained cultural import, there are fundamental differences in the way cultures have interacted with oceans and rivers. Still, the divergence of the scholarly communities Holm noted is largely a continuation of distinctions that trace back to the origins of each field and the scientific trajectories they follow.

While historians have long written about rivers and lakes, the field may be dated to Richard White's slim but seminal The Organic Machine: The Remaking of the Columbia River (1996). White's work has encouraged historians to think of remade rivers as hybrid ecosystems - at once human-made and still essentially natural. Ever since, historians have emphasised the role of rivers in economies, rural and urban, and their stories have tended to centre on the human need to control nature. These themes remain at the heart of subsequent important works, from Marc Cioc's The Rhine: An Eco-biography, 1815-2000 (2006) to Sara Pritchard's Confluence: The Nature of Technology and the Remaking of the Rhône (2011). ${ }^{6}$ Most freshwater histories have focused on rivers, with lakes receiving considerably less attention, the exception being the largest lakes, those that have shaped economic and urban history-the Great Lakes in particular. ${ }^{7}$ Another area of freshwater history has concerned artificial bodies of water, especially canals and reservoirs. ${ }^{8}$ One particular contribution deserves special attention: David Blackbourn's The Conquest of Nature: Water, Landscape and the Making of Modern Germany (2007), which successfully links a cultural desire for predictability with the need to transform the entire aquatic

\footnotetext{
5 Helen M. Rozwadowski, 'Oceans. Fusing the History of Science and Technology with Environmental History', in A Companion to American Environmental History, ed. Douglas Cazaux Sackmand (Malden, MA: WileyBlackwell, 2010), 454, doi.org/10.1002/9781444323610.ch23.

6 Richard White, The Organic Machine: The Remaking of the Columbia River (New York: Hill and Wang, 1996); Marc Cioc, The Rhine: An Eco-biography, 1815-2000 (Seattle, WA: University of Washington Press, 2006); Sara Pritchard, Confluence: The Nature of Technology and the Remaking of the Rhône (Cambridge, MA: Harvard University Press, 2011), doi.org/10.4159/harvard.9780674061231; Paula Schonach, 'River Histories: A Thematic Review', Water History 9, no. 3 (2017): 326, doi.org/10.1007/s12685-016-0188-4. Some historians might date the origins to Donald Worster's Rivers of Empire: Water, Aridity, and the Growth of the American West (New York: Oxford University Press, 1985), or even Karl Wittfogel's Oriental Despotism: A Comparative Study of Total Power (New Haven, CT: Yale University Press, 1957), which greatly influenced Worster. Both of these works, however, are more centrally concerned with 'the flow of power', in Worster's words, than with the flow of water.

7 See, for example, Nancy Langston, Sustaining Lake Superior: An Extraordinary Lake in a Changing World (New Haven, CT: Yale University Press, 2017); William Ashworth, The Late, Great Lakes: An Environmental History (New York: Knopf, 1986); Margaret Beattie Bogue, Fishing the Great Lakes: An Environmental History, 1783-1933 (Madison, WI: University of Wisconsin Press, 2000); William McGucken, Lake Erie Rehabilitated: Controlling Cultural Eutrophication 1960s-1990s (Akron, OH: University of Akron Press, 2000); and Dan Egan, The Death and Life of the Great Lakes (New York: W. W. Norton, 2017).

8 Two exceptional contributions: Mark Fiege, Irrigated Eden: The Making of an Agricultural Landscape in the American West (Seattle, WA: University of Washington Press, 1999); Carol Sheriff, The Artificial River: The Erie Canal and the Paradox of Progress, 1817-1862 (New York: Hill \& Wang, 1992).
} 
environment. More recently, river historians have become especially interested in cities, human settlements striving for permanence and prosperity along bodies of water that are often disappointingly wild and variable. The control of nature, or at least accommodation of nature, remains a central theme in these works. ${ }^{9}$

Ocean history has been less straightforward in its trajectory, in part because the sea has been long regarded as 'an ahistoric place', or 'aqua nullius', according to Helen Rozwadowski and Elizabeth DeLoughrey respectively. ${ }^{10}$ Late to the field of historical inquiry, ocean studies are now a growing and vibrant subfield as scholars attempt to darn the 'blue hole' in environmental humanities. ${ }^{11}$ Ocean scholars are engaging with other subfields, including global, environmental and maritime history. Generally diverse in both approach and methodology, there are three discrete strands of ocean history worthy of attention.

First, there are histories in which oceans serve as an extraterritorial stage, navigated space in which voyages of exploration and conquest are filled with cultural mixing and conflict. ${ }^{12}$ In this strand, the distinction between older works of maritime history, such as Benjamin Labaree et al., America and the Sea, and newer works of ocean history are not always clear-cut. ${ }^{13}$ While there are many precursors, we might date a broader recognition of this strand among general historians to Marcus Rediker's groundbreaking Between the Devil and the Deep Blue Sea: Merchant Seamen, Pirates, and the Anglo-American Maritime World, 1700-1750 (1987). This is the kind of work Bernhard Klein and Gesa Mackenthun imagined as 'historicizing the ocean' in their 2004 collection of essays, in which they describe oceans as spaces where important events happened, where the duality of water bodies - that they simultaneously connect and divide-literally sets the stage for critical human dramas. Growing interest in postcolonial, transnational and global history has

9 David Blackbourn, The Conquest of Nature: Water, Landscape and the Making of Modern Germany (New York: W. W. Norton, 2007). For a quick tour of the rapidly growing field of river history, peruse three collective works: Uwe Luebken, Dieter Schott and Martin Knoll, eds, Rivers Lost, Rivers Regained (Pittsburgh, PA: University of Pittsburgh Press, 2017); Stephane Castonguay and Matthew Evenden, eds, Urban Rivers: Remaking Rivers, Cities, and Space in Europe and North America (Pittsburgh, PA: University of Pittsburgh Press, 2012); Christof Mauch and Thomas Zeller, eds, Rivers in History: Perspectives on Waterways in Europe and North America (Pittsburgh, PA: University of Pittsburgh Press, 2008). Paula Schonach dates the founding of the field to Worster's Rivers of Empire. Another early contribution to the field is Ted Steinberg's Nature Incorporated: Industrialization and the Waters of New England (Amherst, MA: University of Massachusetts Press, 1994).

10 Helen M. Rozwadowski, 'Ocean's Depth', Environmental History 15 (2010): 520-5; Similarly John R. Stilgoe in Alongshore (New Haven, CT: Yale University Press, 1994); Elizabeth DeLoughrey, 'Submarine Futures of the Anthropocene', Comparative Literature 69, no. 1 (2017): 32-44, doi.org/10.1215/00104124-3794589.

11 John Gillis and Franziska Torma, eds, Fluid Frontiers. New Currents in Marine Environmental History (Cambridge: White Horse Press, 2015).

12 Helen M. Rozwadowsi, 'Oceans. Fusing the History of Science and Technology with Environmental History', 442-61.

13 Benjamin W. Labaree et al., America and the Sea: A Maritime History (Mystic, CT: Mystic Seaport, 1998). 
made this approach to maritime history especially lively in recent decades. ${ }^{14}$ Still, as DeLoughrey has pointed out, in these histories the ocean rarely figures as a material in itself: 'With some exceptions, these narratives largely represent a transoceanic imaginary, positioning the sea as a stage for human history; a narrative of flat surfaces rather than immersions.' ${ }^{15}$

A second strand of ocean history considers the seas primarily as habitat-the home of whales and fish, of microbes and corals. ${ }^{16}$ These histories tend to be interdisciplinary, relying on scientists and their technologies as primary sources and, in fact, often taking the science itself as the topic at hand. In 1951, marine biologist Rachel Carson published her seminal book The Sea Around Us, which boosted her career as a writer and conservationist. ${ }^{17}$ Carson's study reveals a fascination with the unknown depths of the ocean that relates back to the nineteenth century. In Fathoming the Ocean: The Discovery and Exploration of the Deep Sea (2005), Helen Rozwadowski explores the rise of the science of the sea. ${ }^{18}$ The edited volume The Machine in Neptune's Garden uses the history of oceanography to explore how people came to know the ocean through technology. ${ }^{19}$ Scholars exploring the ocean as habitat put the ocean itself at the centre of their work, rather than treating it as the space upon which action takes place. Still, similarities between these two strands exist, including the themes of exploration, discovery and conquest, and, of course, that to date ocean history has largely contained anthropocentric narratives. Recent scholarship has begun to explore animal cultures, treating marine mammals and fish as historical actors. ${ }^{20}$

14 See, for example, the Forum 'Oceans of History', with contributions by Kären Wigen (Introduction), Matt Matsuda (Pacific), Alison Games (Atlantic), and Peregrine Horden and Nicholas Purcell (Mediterranean): American Historical Review 111, no. 3 (June 2006); similarly Daniel Finamore, ed., Maritime History as World History (Gainesville, FL: University Press of Florida, 2004). The theme of the sea as simultaneously connecting and dividing is first mentioned by Benjamin Labaree in 'The Atlantic Paradox', in The Atlantic World of Robert G. Albion, ed. Benjamin Labaree (Middletown, CT: Wesleyan University Press, 1975) 195-217.

15 DeLoughrey, 'Submarine Futures of the Anthropocene', 33; Marcus Rediker, Between the Devil and the Deep Blue Sea: Merchant Seamen, Pirates, and the Anglo-American Maritime World, 1700-1750 (Cambridge: Cambridge University Press, 1987); Bernard Klein and Gesa Mackenthun, eds, Sea Changes: Historicizing the Ocean (New York: Routledge, 2004); Sugata Bose, A Hundred Horizons. The Indian Ocean in the Age of Global Empire, (Cambridge, MA: Harvard University Press, 2009).

16 Mark Kurlansky, Cod: A Biography of the Fish That Changed the World (New York: Penguin, 1998); Carmel Finley, All the Boats on the Ocean: How Government Subsidies led to Global Overfishing, (Chicago: Chicago University Press, 2017), doi.org/10.7208/chicago/9780226443409.001.0001.

17 Rachel Carson, The Sea Around Us (New York: Oxford University Press, 1951).

18 Helen Rozwadowski, Fathoming the Ocean: The Discovery and Exploration of the Deep Sea (Cambridge, MA: Belknap Press, 2005). See also Stefan Helmreich, Alien Ocean: Anthropological Voyages in Microbial Seas (Berkeley, CA: University of California Press, 2009).

19 Helen M. Rozwadowski and David K. Van Keuren, eds, The Machine in Neptune's Garden: Historical Perspectives on Technology and the Marine Environment (Sagamore Beach, MA: Science History Publications, 2004).

20 Jeffrey W. Bolster, 'Putting the Ocean in Atlantic History: Maritime Communities and Marine Ecology in the Northwest Atlantic, 1500-1800', American Historical Review 113, no. 1 (2008), 19-47, doi.org/10.1086/ahr. 113.1.19. 
Finally, there is an emerging strand of literature that employs the ocean as a place with which humans interact. We found this strand especially helpful in framing our water history, and from it we take lessons on how to think about oceans and other bodies of water. ${ }^{21}$ In her essay 'Oceans', Rozwadowski challenges environmental historians to broaden their perspective of the ocean, claiming even its remote parts are 'intertwined with human history'. Moreover, she notes that ocean histories:

that deal only with oceanic peoples or those engaged in maritime work will never be as comprehensive as those that also succeed in accounting for the myriad other groups of people who interact with the ocean-consumers, writers, scientists, recreationalists, policymakers, dreamers - some of whom never even see the ocean. ${ }^{22}$

Similarly, we take inspiration from the blue humanities, a cultural re-turn to the ocean primarily in literary studies, which explicates people's imaginary relationships to large bodies of water. ${ }^{23}$ Both approaches remind us that oceans are simultaneously real and imagined - as are rivers and lakes. People do not need to know these bodies of water through science or technology in order to care for them.

Some qualities of oceans — including their vast size, fluidity and opacity — have clearly diminished the range of sources with which scholars can work. Because the span of human interactions with so much of the oceans has been so delimited and because humans have experienced so little of the oceans, historians are especially beholden to science and technology as a primary source, particularly when creating deeper narratives-deeper both physically and chronologically. As DeLoughrey writes, 'the sea dissolves phenomenological experience and diffracts the accumulation of narrative'. These qualities of water add special challenges to the evolution of ocean history. ${ }^{24}$

Work in both freshwater and ocean history has expanded rapidly in recent decades, encouraged by a variety of scholarly trends, ranging from geographers' proposal of 'wet ontologies' and 'fluid spaces', to the growth of environmental humanities and especially the blue humanities, a movement in literary and cultural studies that focuses on the presence of the ocean in cultural texts. ${ }^{25}$ The initiation of the journal Water History in 2009 announced the arrival of a new, legitimate field, and seemingly promised to bridge the divide between fresh and saltwater history. But its pages have been filled almost entirely with freshwater articles concerning canals,

21 For instance, Philip E. Steinberg, The Social Construction of the Ocean (Cambridge: Cambridge University Press, 2001).

22 Rozwadowski, 'Ocean', 442.

23 Steven Mentz, 'Toward a Blue Cultural Studies: The Sea, Maritime Culture, and Early Modern English Literature', Literature Compass 6, no. 5 (2009), 997-1013, doi.org/10.1111/j.1741-4113.2009.00655.x.

24 DeLoughrey, 'Submarine Futures of the Anthropocene', 33.

25 Philip Steinberg and Kimberly Peters, 'Wet Ontologies, Fluid Spaces: Giving Depth to Volume through Oceanic Thinking', Environment and Planning D: Society and Space 33, no. 2 (2015), doi.org/10.1068/d14148p. Steven Mentz' book At the Bottom of Shakespeare's Ocean (London: Continuum, 2009), doi.org/10.5040/9781472554833, is one of the founding publications in the genre of blue humanities; see also his essay 'Toward a Blue Cultural Studies'. 
wetlands and, especially, the relationships between cities and rivers. The journal's introductory editorial, co-authored by the 15 -member editorial board, made a plea for water history as a critical field of study, one that should be expansive and explicitly interdisciplinary. As such, the editors provided no guidance on how the field should evolve methodologically and theoretically. ${ }^{26}$ In 2015, Water History published an essay by Rila Mukherjee, 'Approaching a History of Water', which made the case for linking ocean and river histories, largely through a world history lens, in which neither national boundaries nor oceanic limits properly define historical narratives. Although Mukherjee suggests 'aquatic qualities' should help define the field, her work uses water mostly as the means of connecting and reconstructing cultural histories-human events that are played out on and in interaction with oceans, bays and rivers. We propose a more material approach, one that puts the qualities of water at the centre of historical analysis and narrative. ${ }^{27}$

Water historians have struggled with scale. The flow of water in rivers and the expansiveness of oceans pull narrative boundaries ever outward..$^{28}$ We have found that both fresh and saltwater historiographies tend to approach their water histories from a container perspective-one based on the geomorphological formations that contain the particular body of water under study. Ocean, lake and reservoir water is contained in depressions of the earth's surface. In the case of oceans, of course, the enormous breadth and depth of their containers have primarily defined human relationships to these bodies-and how historians have described them. River history, in turn, seems to take literally the linguistic origin of the term 'river'-deriving from the Latin word riparia, which signifies the banks of a river and its bordering functions as a geomorphological formation. This formation creates a boundary between water and land and marks off aquatic and terrestrial ecosystems. ${ }^{29}$ We propose to move beyond the container perspective and beyond the contours of watersheds, to look beneath the surface, to the physical characteristics of water and people's simultaneously real and imaginary understanding of them.

26 Johann Tempelhoff et al., 'Where Has the Water Come From?', Water History 1, no. 1 (2009), 1-8, doi.org/ 10.1007/s12685-009-0003-6. Similarly, in 2012, RCC Perspectives published a special issue 'On Water', bringing together contributions from fresh and saltwater historians.

27 Rila Mukherjee, 'Approaching a History of Water', Water History 7, no. 2 (2015), 159-77, doi.org/10.1007/ s12685-015-0136-8. See also Rila Mukherjee, ed., Oceans Connect: Reflections on Water Worlds Across Time and Space (Delhi: Primus Books, 2013), a collection of essays that describe oceans as space upon which events have taken place. 28 'Sea Flows: Mobility, Boundaries, and Scale in Marine Environmental History' panel at the 2017 American Society for Environmental History Conference in Chicago.

29 Schönach, 'River Histories', 240. As Ruth Morgan points out, this tendency is also evident in the ways that swamps and wetlands have been understood - as neither wet nor dry, which make it difficult for the state to map and control. 


\section{The qualities of water: A material perspective}

Environmental historians have struggled with and disagreed about the question of agency-how much to assign to nature and how much to reserve for humans. To varying degrees taking inspiration from approaches such as Karen Barad's Meeting the Universe Halfway (2007), Donna Haraway's When Species Meet (2007) or Bruno Latour's Reassembling the Social (2005), there is still broad agreement about the value of a material approach, making the physical world omnipresent in human narratives. ${ }^{30}$ Water histories too often disregard the materiality of water, the physical and chemical properties of the element itself - the properties that have defined its role as an agent in history. These properties pertain to water anywhere it is found in the hydrological cycle, irrespective of the water's container, and so should be relevant to narratives in fresh and saltwater settings. The material qualities of water drew our two stories — of river dredging and ocean dumping — into one analytical frame, allowing us to evaluate the similarity of people's interactions with bodies of water.

Some of these properties are so elemental that historians assume and ignore them. Most fundamentally, water predominantly takes a liquid or gaseous form on earth, and so it is highly mobile. The fluidity of water is essential to rivers, of course, but no less so to oceans, where currents and tides make the sea a place of constant motion. Combined with a certain degree of tracklessness, this fluidity-and what it does to land-based understandings of place-must play some role in both fresh and saltwater histories. One of the challenges in confronting open-water dumping has been precisely locating dump sites to assess environmental harm. In the era before GIS, repeatedly navigating a ship to the very same spot, to locate something drowned that water currents might have moved elsewhere, posed significant challenges. Of course, in the case of rivers, the flow of water was the single greatest advantage for disposal-since waste moved downstream, out of sight and out of reach.

Perhaps nearly as important, certainly to the history of open-water disposal, are the interactions between water and light. Although they vary tremendously depending upon their turbidity, bodies of water are never fully transparent. Light reflects and refracts upon hitting the surface; light slows when passing through water, distorting size and distance, and ensuring darkness at depth. This interaction with light has given bodies of water mysterious qualities, making them homes to mythical creatures as well as natural hiding places for unwanted materials_-from toxic waste to murder

30 Karen Barad, Meeting the Universe Halfway (Durham, NC: Duke University Press, 2007), a volume in which the theoretical physicist and feminist theorist Barad explains her theory of agential realism; Donna Haraway, When Species Meet (Minneapolis, MN: University of Minnesota Press, 2007), an exploration of the intersection between humankind and dog; Bruno Latour, Reassembling the Social (Oxford: Oxford University Press, 2005). 
weapons. ${ }^{31}$ For centuries, water bodies have been the most common disposal site for sewage, dredge spoil and industrial waste, and in the Cold War era they became a dumping ground for unwanted, dangerous chemical weapons.

When combined, these most fundamental qualities of water-fluidity and opacity - set the stage for the story we tell here. The opacity of the Great Lakes and the Atlantic Ocean helped make them appealing places to discard waste, but their fluidity, together with the ability of other chemicals to diffuse through water, made them problematic disposal sites. Unwanted materials might stay hidden, but they were unlikely to stay put. And so, in the age of ecology, as more and more citizens ask questions about common disposal practices, bodies of water increasingly became unsatisfactory locations for waste disposal..$^{32}$

Although materiality generated public concern, decision-making and policy formation came down to human structures of power. The idea of the anthropocenean epoch when human activities significantly impact geological, biotic and climatic processes - has influenced recent trends in environmental humanities. As authors push stories towards a planetary scale, they intend to free narratives from an anthropocentric lens that has defined the humanities. Methodologically dethroning the human as the centre of the universe does allow researchers to seriously engage with questions of multi-species interactions, new temporalities and materialities. It locates the human as one element among many within an entire planetary ecosystem. ${ }^{33}$ In the field of environmental law, for instance, such a post-humanist perspective has given rise to the rights of nature movement that has a particular fervour in Latin America. Rather than treating nature as property under the law,

31 See Franziska Torma, 'Snakey Waters, or: How Marine Biology Structured Global Environmental Sciences', in On Water: Perceptions, Politics, Perils, ed. Agnes Kneitz and Marc Landry (Munich: Rachel Carson Center, 2012), 13-21; Natascha Adamowsky, The Mysterious Science of the Sea, 1775-1943 (London and New York: Routledge, 2015).

32 We should note that there are many other properties of water that have shaped its role as an historical actor, some of which play no role in our story. Perhaps most fundamentally, water is essential to human life, and so water in its many forms has acquired spiritual qualities that we do not discuss. See, for example, Tsu Yun Hui, 'Between Heaven and the Deep Sea: The Religious Practice of Chinese Seafarers from the Eleventh to the Mid-nineteenth Century', East Asian History 23 (2002): 69-86; Nick Verouden and Frans J. Meijman, 'Water, health and the body: The tide, undercurrent and surge of meanings', Water History 2, no. 1 (2010): 19-33, doi.org/10.1007/s12685010-0019-y. On the chemical side, when water turns into a solid, it becomes less dense, the property that makes ice float and makes icebergs an actor on the world stage — at least in extreme latitudes. Water's icy quality plays an important role in scholarship on Eastern Europe. See Julia Herzberg, 'The Domestication of Ice and Cold: The Ice Palace in Saint Petersburg 1740', in On Water: Perceptions, Politics, Perils, ed. Agnes Kneitz and Marc Landry (Munich: Rachel Carson Center, 2012), 53-62.

33 Bruno Latour, Facing Gaia: Eight Lectures on the New Climatic Regime (Cambridge: Polity, 2017); Dipesh Chakrabarty, 'Humanities in the Anthropocene: The Crisis of an Enduring Kantian Fable', New Literary History 47 (2016): 377-97; Jason Moore, Capitalism in the Web of Life: Ecology and the Accumulation of Capital (London: Verso, 2015). 
rights of nature acknowledges that nature has 'the right to exist, persist, maintain and regenerate its vital cycles' ${ }^{34}$ In 2017, for instance, the Colombian Constitutional Court granted legal rights to the Atrato River. ${ }^{35}$

At the same time, such post-humanist and planetary approaches bear danger of two kinds. On the one hand, water's qualities do not make open-water dumping inherently attractive. Human perspectives on water's material qualities - the cultural appropriation of these aqueous characteristics-led to the dumping. On the other hand, post-humanist and planetary approaches may lead to levelling all humans as one kind. ${ }^{36}$ The human-material relationship, in our case the question of how our human actors relate to water, is strongly determined by location and economic and political background, as well as cultural heritage. Human connections to the element of water and to specific bodies of water are cultural and personal, historical and emotional. While we embrace the material perspective in our story, we still see the categories of race, class and gender as they are embedded in an analysis of power relationships as highly relevant.

\section{The materiality of water: Disposal, activism, science and policy}

Water readily covers up almost anything drowned beneath its surface. From the surface, water can appear placeless, a continuous, undifferentiated plane. Dropped out of sight, drowned objects easily fall out of mind as well. For centuries, people have made use of this particular characteristic of water by dumping unwanted material in oceans, rivers, lakes or creeks.

Large-scale open-water dumping began in the early twentieth century and increased dramatically in the two decades after the Second World War. American municipalities, industries and federal agencies expanded open-water dumping in the New York Bight, the Gulf of Mexico, the Santa Monica Submarine Canyon and the Great Lakes, among other places. By 1972 almost 250 official dump sites existed off US coasts (122 Atlantic, 56 Gulf of Mexico, 68 Pacific). ${ }^{37}$ Additionally, estuaries

34 Global Alliance for the Rights of Nature, 'What is Rights of Nature?', 2017, therightsofnature.org/what-isrights-of-nature, accessed 12 October 2017.

35 Nick Mount, 'Can a river have legal rights?' The Independent, 13 October 2017.

36 This critique came out of a reading group discussion on the above texts of the research group Hazardous Travels: Ghost Acres and the Global Waste Economy, Rachel Carson Center, in the fall of 2017; similarly Dagmar Lorenz-Meyer et al., 'Anthropocene Ecologies: Biogeotechnical Relationalities in Late Capitalism' (2015), position paper for Working Group 2 of the COST Action IS1307 New Materialism: Networking European Scholarship on 'How Matter Comes to Matter', newmaterialism.eu/content/5-working-groups/2-working-group-2/positionpapers/anthropocene-ecologies-15.12.pdf, accessed 30 September 2017.

37 Council on Environmental Quality, Report of the Council on Environmental Quality on Ocean Dumping, (Washington, DC: US Government Printing Office, 1970), 1. 
such as Delaware Bay, inland waterways and lakes, large and small, served as 'huge open sewers', according to the Florida Congressman Charles E. Bennett. ${ }^{38}$ No one kept track of how much was dumped in the immediate post-war era, let alone determined whether or not the material was problematic for human or ecological health. Only when conducting a first ocean dumping study in 1970 did the newly established US Council on Environmental Quality (CEQ) attach numbers to the problem: about 48 million tons had been dumped at sea in 1968 alone. This total included industrial waste, sewage sludge, construction debris, solid waste, explosives, chemical munitions, radioactive waste and various miscellaneous material. ${ }^{39}$

By the 1960s, dredge spoil accounted for about 80 per cent by weight of the material dumped in open water-in the Atlantic Ocean, Pacific and Great Lakes-rising to almost 90 per cent by weight by the mid-1970s. About 34 per cent of the dredge spoil was polluted, according to the CEQ.$^{40}$ Dredging and dumping stirred up pollutants found in the sediments, releasing them into the overlaying water and creating serious physical and chemical effects, such as lowering the available oxygen content of the bottom water and allowing chemicals to enter the marine food chain. ${ }^{41}$ Even before post-war harbour expansions, the US Army Corps of Engineers had established open-water spoil disposal sites throughout the Great Lakes and along the Atlantic and Pacific shores. The Corps used these dump sites for their own dredge material, and it supervised a permit system for material dredged by contractors. ${ }^{42}$ Because distance greatly added to the cost, disposal sites clustered near harbours, often impacting estuaries and wetlands. ${ }^{43}$

38 Charles E. Bennett, cited in Subcommittee on Fisheries and Wildlife Conservation; Subcommittee on Oceanography, Ocean Dumping of Waste Materials. Hearings (Washington, DC: US Government Printing Office, 1971), 152.

39 Council on Environmental Quality, Ocean Dumping, 1970, 1, 10.

40 US Army Corps of Engineers, Dredging and Water Quality Problems in the Great Lakes ([Buffalo, NY: US Army Corps of Engineers, Buffalo District], June 1969), 80-9; International Working Group on the Abatement and Control of Pollution from Dredging Activities, Report (1975), International Joint Commission (IJC) Digital Archive, 31, scholar.uwindsor.ca/ijcarchive/67, accessed 1 December 2018. On the St Lawrence Seaway, see Daniel MacFarlane, Negotiating a River: Canada, the US, and the Creation of the St. Lawrence Seaway (Vancouver: UBC Press, 2014); Council on Environmental Quality, Ocean Dumping, 3.

41 Kenneth S. Kamlet, cited in Subcommittee on the Environment and Atmosphere, The Environmental Effects of Dumping in the Oceans and Great Lakes, Hearing (Washington, DC: US Government Printing Office, 1976), 35. 42 While the Corps of Engineers gave out permits for dredge-spoil dumping in ocean water, the Environmental Protection Agency regulated all other forms of ocean dumping: Albert R. Capellini, 'Ocean Dumping', in The Handbook of Hazardous Waste Management, ed. Amir Metry (Westport, CT: Technomic Publishing, 1980), 405.

43 US Army Corps of Engineers, Dredging and Water Quality Problems in the Great Lakes, 97-102; US Army Corps of Engineers, Dredging and Water Quality Problems in the Great Lakes: A Pilot Program Summary ([Buffalo, NY: US Army Corps of Engineers, Buffalo District], 1969), ix; Federal Water Pollution Control Administration, Proceedings: Progress Evaluation Meeting —Pollution of Lake Erie and its Tributaries_Indiana, Michigan, New York, Ohio, Pennsylvania ([Washington, DC: US Government Printing Office], 4 June 1968), 156. On Lake Ontario, the two largest dredge sites were Canadian: Toronto and Hamilton. 
For communities, industries and government agencies alike, the various attractions of dumping in water were in its relative ease, its obvious convenience, and its economic efficiency'. ${ }^{44}$ At the time, about 85 per cent of Americans lived in coastal environments. ${ }^{45}$ As they were facing 'decreasing capacity of existing disposal facilities, lack of nearby land sites, higher costs and political problems in acquiring new sites', over the course of the 1960s it was convenient to simply drop the material beneath nearby waters. As a participant at the 1966 international conference on ocean dumping pointed out, the 'great economy' of discharging urban sewage, industrial waste or dredge spoil into near-shore waters was 'inherent'. If these waters could be reached 'within the bounds of economy, the grim spectre of an expensive treatment plant grew dimmer and dimmer ... to the great satisfaction to those ... who have to pay the bill'. In the end, the 'good old ocean [did] the job free'. ${ }^{46}$

At the time, people further assumed that there would be no environmental harm done to the oceans, America's coastal waters or the Great Lakes-given their vastness and fluidity. Through much of human history flowing water was the most desirable disposal site, since water flushed away waste. Along Ohio's Cuyahoga River, for instance, it mattered greatly whether you lived up or downstream. People also thought that large water bodies diluted whatever was put in them through the sheer quantity of water available. They represented an 'unlimited ... reservoir for waste assimilation', so a widespread belief up until the 1970 s. ${ }^{47}$ For instance, when interrogated about the dumping of chemical weapons in 1970, Under Secretary of the Army Thaddeus Beal argued that 'immersing' outdated chemical weapons in sea water would 'dilute and detoxify the chemical agent when it escape[d] from the vaults'. While they could not guarantee that there would be 'absolutely no effect on the environment at the disposal site', they believed it would be 'inconsequential'. ${ }^{48}$ Lake Erie, too, received dredge spoil for decades without raising alarm, the tainted silt sinking out of consciousness. The Great Lakes, estuarial and marine waters alike seemed to be ideal 'ultimate sinks' for unwanted materials. ${ }^{49}$

Finally, the depth of some of these waters and the near impossibility of recovering drowned objects added to the attraction of open-water dumping of some of the most toxic waste, such as explosives, chemical munitions and nuclear waste. During the Cold War, the US military had turned ocean dumping into a large-scale military

44 Stuart Weinstein-Bacal, 'The Ocean Dumping Dilemma', Lawyers of the Americas 10, no. 3 (1987): 887.

45 Subcommittee Fisheries and Oceanography, Ocean Dumping of Waste, 119.

46 Cited in Subcommittee on Fisheries and Wildlife Conservation; Subcommittee on Oceanography, Ocean Dumping, 138.

47 Subcommittee on Fisheries and Wildlife Conservation; Subcommittee on Oceanography, Ocean Dumping, 138.

48 Subcommittee on Oceanography, Dumping of Nerve Gas Rockets in the Ocean. Hearing (Washington, DC: US Government Printing Office, 5 August 1970).

49 Weinstein-Bacal, 'The Ocean Dumping Dilemma', 869; In Poison in the Well (New Brunswick, NJ: Rutgers University Press, 2008), Jacob Hamblin explores the history of radioactive waste ocean dumping between 1945 and 1972. See also Joel Tarr, The Search for the Ultimate Sink: Urban Pollution in Historical Perspective (Akron, OH: University of Akron Press, 1996). 
operation to remove outdated chemical weapons from its stockpile. ${ }^{50}$ In 1964 it initiated Operation CHASE — an acronym for 'cut holes and sink 'em' and the title of a series of military missions scuttling old naval ships at sea. On board were tons of unwanted chemical weapons to be drowned together with the ships. ${ }^{51}$ Even though the US military conducted the dumping, later it had great difficulty mapping the exact site of their dumps. As a naval spokesperson at the Pentagon pointed out at a congressional hearing in 1970, the ocean was 'not like a highway where you can go to an exact spot'. ${ }^{52}$ Often these weapons literally were irretrievably lostwhich theoretically served the purpose of preventing them from falling into the wrong hands.

The practice of open-water dumping relied on the ocean's ability to put unwanted objects out of sight and out of reach. Water's fluidity, however, together with the ability of other chemicals to diffuse through water, made open waters problematic disposal sites. Always imperfect as a disposal system, dumping in fluids became even more problematic when the waste contained toxic and persistent chemicals, such as heavy metals, PCBs (printed circuit boards) or dioxin. Unwanted materials might stay hidden, but they were unlikely to stay put.

In the 1960s and 1970s, as ecological knowledge began to work its way into public discourse and policy formation, the opacity of water began to lose its magical power to hide waste. Scientists and citizens began to peer beneath the waters, using all manner of research to discover the potential ill effects of open-water waste disposal. Growing public awareness of environmental problems and ecological science in 1960s_combined with a deteriorating urban-industrial environment—encouraged a fledgling public movement against open-water dumping in the Great Lakes, estuaries and ocean. Water's physical properties made open-water disposal sites poor places for protest, especially since they lost their distinctiveness soon after materials became submerged. ${ }^{33}$ Still, activists concerned with pollution found governmental committee meetings, scientific conferences and the pages of newspapers to be effective sites of protest and discussion.

By the early 1960s, citizens around the Great Lakes began to express concern about open-water dumping. To the general public, the annual ritual of dredging and disposal was the most visible material connection between polluted waters, such as Cleveland's Cuyahoga River, and more valued and natural locations, such as Lake Erie. In an earlier era the vast majority of Americans would have described

50 DeLoughrey, 'Submarine Futures of the Anthropocene', 1.

51 Müller, “'Cut Holes and Sink 'em”: Chemical Weapons Disposal and Cold War History as a History of Risk', Historical Social Research 41, no. 1 (2016): 270.

52 'Appeal on Seabed Dumping', The Times (London), 21 August 1970.

53 Part of Greenpeace's influence in the years after our story ends derived from its ability to turn the open water into an effective site of protest. See Frank Zelko, Make it a Green Peace! The Rise of Countercultural Environmentalism (New York: Oxford University Press, 2013). 
dredging and open-water dumping as simply essential to the industrial economy; by the mid and late 1960s, the public increasingly perceived dredging and dumping as the intentional movement of urban pollution into an unspoiled ecosystem-the open water. Like images of the Cuyahoga River burning, scenes of barges dumping spoil into the lake struck an increasing number of observers as problematic, without knowing exactly why. One did not need to know the specific ecological consequences of open-water disposal to argue that the lakes should not be treated as a dump. ${ }^{54}$

Environmental groups in the region became among the first activists to work toward ending the practice, with the goal of protecting water-based recreation, especially swimming and fishing. ${ }^{55}$ Among the activists was John Chascsa, president of the Lake Erie Clean-up Committee, formed in 1961 in response to threats to the Detroit River and western Lake Erie. 'The purpose of our Committee', he said in 1962 , 'is to eliminate human suffering because of pollution, a national scourge; to encourage further scientific research with regard to waste disposal; to make available our lakes and streams once more for fish, recreation, and consumption. ${ }^{56}$

From the Great Lakes, concern about open-water dumping of pollutants spread around the New York Bight and Delaware Bay over the course of the 1960s. By the end of the decade, even the vast container of the Atlantic garnered concern. In 1969, New York Congressman Richard D. McCarthy uncovered information about the military's CHASE missions. Dropped in an atmosphere of anti-militarism and antiVietnam protests, his information about the secret military operations became top news. ${ }^{57}$ Protests against Operation CHASE opened a can of worms, triggering a vigorous public and then political debate on 'ocean dumping'. By 1970, all US coastal waters, including estuaries and the Great Lakes, were coming under scrutiny, and very soon 'ocean dumping' became the term to refer to all of these bodies of water and the environmental damage inflicted upon them through waste disposalthe perfect rhetorical evidence that waste and water mattered in these stories, while salinity did not. ${ }^{58}$

As with the early anti-dumping protests around the Great Lakes in the early 1960s, debates on open-water dumping in the early 1970s focused on 'the protection of marine life and oceans' recreation resources'. Now, however, the fishing and tourism

54 David Stradling and Richard Stradling, Where the River Burned: Carl Stokes and the Struggle to Save Cleveland (Ithaca, NY: Cornell University Press, 2015), 122-6.

55 Terence Kehoe, Cleaning Up the Great Lakes: From Cooperation to Confrontation (Dekalb, IL: Northern Illinois University Press, 1997), 56-7, 61-3. See also Terrianne K. Schulte, 'Grassroots at the Water's Edge: The League of Women Voters and the Struggle to Save Lake Erie, 1956-1970' (PhD diss., State University of New York at Buffalo, 2006). Interestingly, altogether Kehoe, McGucken and Schulte wrote very little about dredging.

56 US Department of Health, Education, and Welfare, Transcript of Conference in the Matter of Pollution, 524.

57 On environmentalism and anti-Vietnam War protests see Adam Rome, "Give Earth a Chance":

The Environmental Movement and the Sixties', Journal of American History 90, no. 2 (2003): 525-54.

58 The full subtitles of all the subcommittee hearings cited here talk about dumping in the ocean and the Great Lakes. 
industries were more directly engaged. In March 1971, the Senate Subcommittee on Air and Water Pollution met in Rehoboth, New Jersey, to discuss in situ the dumping of waste into the ocean-only to be met by 'a tremendous turnout' in local audience for their hearing. ${ }^{59}$ Those working the coastal waters were concerned about the 'considerable long-term damage from unregulated dumping of waste', as well as the 'economic consequences', which already had 'spelled disaster' for some of them. At the time, New Haven Harbor no longer yielded edible shellfish. ${ }^{60}$ At a congressional hearing later in 1971, New Jersey Congressman Charles W. Sandman warned that 'one of the Nation's most historic, basic and important industries may well be threatened with near extinction because of ocean pollution'. ${ }^{61}$

To turn activism against open-water dumping into legislation, knowing the problem became key. While the public demanded an end to open-water dumping, both the Corps of Engineers and the US Army were hesitant. Since alternatives could add significantly to the waste disposal, neither would change policy before it had data on the actual environmental effects. Only scientific research could justify the expense of alternative disposal methods. Although researchers had been studying fresh and saltwater environments for decades by the early 1970s, the modern fields of oceanography and limnology, a lack of knowledge about the ecological consequences of open-water dumping impeded policy formation. The scale of both the Great Lakes and the Atlantic Ocean - their width, their breadth, but most of all their depth—slowed knowledge accumulation. ${ }^{62}$

The more general problem was that up to that point questions about the effects of open-water dumping had primarily come from 'an obscure group of scientists, known as ecologists', as Alton Lennon, North Carolina Congressman and chairman of the Subcommittee on Oceanography, pointed out in $1971 .{ }^{63}$ Neither in the case of dredge spoil in the Great Lakes, nor in that of dumping chemical weapons in the Atlantic, had those doing the dumping conducted scientific studies on its effects. The Army, for instance, seldom left any precise records of what it had dumped where, or followed up to see what, if any, impact its dumping had had on marine life. When in 1969 it had to respond to Congress for charges of ocean pollution, its experts only managed to gather data on the damage inflicted on the marine

59 Committee on Public Works, Water Pollution Control Legislation. Ocean Dumping (Washington, DC: US Government Printing Office, 1971), 1910.

60 Robert Giaimo, cited in Subcommittee on Fisheries and Wildlife Conservation; Subcommittee on Oceanography, Ocean Dumping, 149.

61 Charles W. Sandman, cited in Subcommittee on Fisheries and Wildlife Conservation; Subcommittee on Oceanography, Ocean Dumping, 211.

62 Rozwadowski's early history of oceanography does not mention limnology, a field that needs an historian. For a start see David G. Frey, ed., Limnology in North America (Madison, WI: University of Wisconsin Press, 1963), esp. 667-82.

63 Alton Lennon, cited in Subcommittee on Fisheries and Wildlife Conservation; Subcommittee on Oceanography, Ocean Dumping, 1. 
environment four days before they were scheduled to appear. ${ }^{64}$ Similarly, the Corps of Engineers had done very little testing at dump sites in the Great Lakes, although it was aware of the 1964 tests of a disposal area abandoned in 1957, which found mud flats that were essentially the same as those found throughout the central basin. Seven years after dumping ceased, the site showed 'no evidence of previous disposal of polluted dredgings'. As late as 1969, the corps continued to ask: 'Just how polluted is the dredged material? What happens to this material, and to pollutants it may contain, after being dumped into deep water; and what is the effect on lake water quality and ecology?'65

After the enactment of the National Environmental Policy Act in 1970, the Corps of Engineers was required to create environmental impact statements for all dredging projects. The reports tended to lack detailed scientific support for either the cessation or continuation of open-water dumping, but they did universally include the higher cost of alternatives. ${ }^{66}$ The situation was such that scientists, the Army and the Corps operated with different data sets, making it difficult to come to sciencebased conclusions on the ecological effects of open-water dumping. Those hoping to study ecological effects often did not have data on the amount, characteristics or whereabouts of dumped material, in particular when it concerned the secret CHASE missions. Those in possession of detailed information on the dumping did not collect data on its effects. Meanwhile, Congress was eager to pass legislation on ocean dumping to appease an outraged public, and policymakers did not seem to care too much that there had 'never been a comprehensive program to determine what kinds [of waste could] be safely disposed of in which waters ${ }^{67}$

Over the course of 1971, the two subcommittees on Fisheries and Wildlife Conservation, and Oceanography considered more than 40 different bills on ocean dumping introduced by different congressmen. ${ }^{68}$ While the bills differed substantially, they all shared a broad notion of the matter being one of water pollution, irrespective of whether it contained salt or not. Nearly every bill covered 'any of the navigable waters of the United States' (House of Representatives, 337, 549, 1381), 'oceans, coastal and other waters' (House of Representatives, 4247, 4723, 5239, 5268, 5477) or, more explicitly, 'oceans, coastal and other waters which would include oceans, gulfs, bays, salt-water lagoons, salt-water harbors, other coastal waters where the tide ebbs and flows, and the Great Lakes and so on' (H.R. 808). ${ }^{69}$ What congressmen,

64 Müller, “"Cut Holes and Sink 'em”, 278-9.

65 'Lake Dumping Study is Inconclusive After 2 Years', Cleveland Plain Dealer, 20 March 1969; US Army Corps of Engineers, Dredging and Water Quality Problems in the Great Lakes, 185; US Army Corps of Engineers, Dredging and Water Quality Problems in the Great Lakes: A Pilot Program Summary, 3.

66 See for example, US Army Corps of Engineers, Diked Disposal Facility, Site No. 14, Lake Erie, Cleveland Harbor, Cleveland, $\mathrm{OH}$ ([Buffalo, NY: US Army Corps of Engineers, Buffalo District],1976).

67 Subcommittee on Fisheries and Wildlife Conservation; Subcommittee on Oceanography, Ocean Dumping, 120.

68 ibid., 144.

69 ibid., 41-63, 141. 
the media and the public alike discussed as 'ocean dumping' throughout the early 1970s actually covered both oceans and Great Lakes, making no distinction between fresh and salt water. Interestingly, the Marine Protection, Research, and Sanctuaries Act, passed in the fall of 1972, no longer contained such a broad understanding of open-water dumping. Public Law 92-532, which also became known as the Ocean Dumping Act, regulated the dumping 'into ocean waters', with 'ocean waters' defined as 'those waters of the open sea laying seaward of the base line from which the territorial sea is measured'..$^{70}$ However, the law did not ignore the Great Lakes entirely, as the act called for a comprehensive study program on the effects of 'ocean dumping' into 'ocean waters or other coaster waters', and explicitly 'the Great Lakes or their connecting waters'. The law also empowered the Secretary of Commerce to create 'marine sanctuaries' in ocean waters and the Great Lakes. ${ }^{71}$

\section{Conclusion}

As early as elementary school, students learn the basics of the hydrological cycle, the continuous movement of water on earth. Arrows point from open waters to the sky, symbolising evaporation. In the atmosphere, water condenses into clouds, then, arrows pointing down, it falls as precipitation. Back on earth, water gathers as ice or snow, or runs off into streams and rivers, sometimes seeping into the groundwater, but always-however slowly-moving back to the oceans, only to be met again by arrows pointing skyward. Given all this movement and the consequent ecological and social connections between rivers, lakes and oceans, historians of water have remained surprisingly confined. The historiographies of salt and fresh waters have remained remarkably distinct. Historians of rivers and lakes can carry on their work as if ocean historiography does not exist, and vice versa. In other words, a true water history field that links both fresh and saltwater history has yet to evolve. ${ }^{72}$

This article has made the case for a truly united field of water history, in which fresh and saltwater historians participate in the creation of a unified historiography. If water historians of all types more consistently considered the qualities of water, allowed its flows to set the scale and shape of our narratives, for example, water could become an agent not just in our histories, but in our historiography. If historians focused on the materiality of water-if the water were made more present-they would of necessity write environmental histories in which the qualities of water would help frame projects and pose questions. In this article, we have brought together two stories that had been researched separately, in which the actors themselves begged for the confluence of their stories of open-water dumping. Only over the course of

70 US Public Law 92-532, 1.

71 US Public Law 92-532, 9, 10.

72 For a useful exploration of the hydrological and hydrosocial cycles, see Jamie Linton, What is Water? The History of a Modern Abstraction (Vancouver: University of British Columbia Press, 2010). 
writing this article did we bring our research together. No doubt our telling and perhaps our conclusions would have been richer had we framed the stories together from the outset. We encourage other scholars to take this approach.

From our research, we have learned that the separation of salt and freshwater bodies was an unnatural one for many of our actors-politicians, activists or journalists. In our stories, water's tendency toward liquidity and opacity seemed to be key to how our actors defined and related to the different bodies of water. These qualities allowed some actors to consider rivers, lakes, estuaries, bays and the oceans equally suitable as ultimate sinks — at least up to the mid-1960s. Then, in political and legislative debates, ocean dumping came to encompass both the oceans and the Great Lakes. Scale only mattered in terms of making changes in water quality observable for those who lived nearby. By the mid-1960s, both Lake Erie and the New York Bight were described as dead because of dumping. Concern about the North Atlantic followed, when news of Operation CHASE gave people a possible explanation for environmental changes they had been observing. Knowing their water through science and technology, surprisingly, played only a minor role in activating concern, opposition and political action. Instead, the multifaceted human relationship to water drove environmental activism.

What would historians gain from a true water history? Fresh and saltwater historians in conversation could learn from each other's methodological approaches and theoretical foundations. Freshwater historians might become more keenly aware of the science that describes the unseen world beneath the surface. Limnology might begin to influence freshwater histories as much as oceanography has the histories of the sea. River historians, usually comfortable working with case studies of specific sites or watersheds, might become more aware of the limits of local histories in a water-connected world. Conversely, ocean historians might consider restricting scale, recovering a placeness in their stories, engaging more fully with the materiality of specific spaces within the seas.

Perhaps more generally, a historiography driven by the materiality of water might broaden the field for future studies, to include not only rivers, oceans and lakes, but any 'container' of water, including clouds, rain and ice, as well as the absence of water: droughts. Regardless of how the field evolves, however, climate change has made water a more active agent around the globe, with rising sea levels, breaking ice shelves, droughts, floods and 'superstorms' threatening to change human relationships to the environment. The more active water becomes and the more scientists learn about aquatic ecosystems - freshwater and saltwater-the more scholars of all disciplines are likely to take up the topic. 
This text is taken from International Review of Environmental History, Volume 5, Issue 1, 2019, edited by James Beattie, published 2019 by ANU Press, The Australian National University, Canberra, Australia.

doi.org/10.22459/IREH.05.01.2019.03 